PACS: 71.15.Mb; 71.20.-b; 71.55.Ak

\title{
FIRST PRINCIPLES CALCULATIONS FOR ELECTRONIC, OPTICAL AND MAGNETIC PROPERTIES OF FULL HEUSLER COMPOUNDS
}

\author{
(D)Sukhendera, (D) Pravesh Pravesh ${ }^{\mathrm{b}}$, (D) Lalit Mohan ${ }^{\mathrm{a}}$, (D) Ajay Singh Verma*,a \\ ${ }^{a}$ Department of Physics, Banasthali Vidyapith \\ Banasthali 304022, India \\ ${ }^{b}$ Department of Electronics and Communication Engineering, KIET Group of Institutions \\ Ghaziabad, Uttar Pradesh (India) 201206 \\ *Corresponding Author: ajay_phy@rediffmail.com \\ Received April 20, 2020; accepted May 30, 2020
}

For the investigation of structural, electronic, optical and magnetic properties of $\mathrm{Co}_{2} \mathrm{CrZ}(\mathrm{Z}=\mathrm{In}, \mathrm{Sb}$, Sn) compounds, we have used two different methods. One is based on full potential linearized augmented plane wave (FP-LAPW) method as implemented in WIEN2k and second is pseudo potential method as implemented in Atomistic Tool Kit-Virtual NanoLab (ATK-VNL). These compounds show

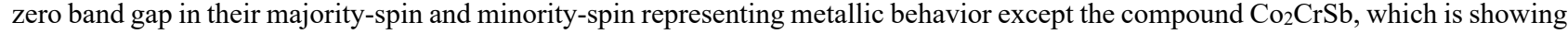
the band gap $0.54 \mathrm{eV}$ in their minority-spin near the Fermi level and viewing $100 \%$ spin polarization; which is implemented in WIEN2k code. Further, the compound $\mathrm{Co}_{2} \mathrm{CrSb}$ has been found to be perfectly half-metallic ferromagnetic (HMF). However, above mentioned compounds show zero band gap in ATK-VNL code. Calculations performed using WIEN2k code shows the magnetic moment of these compounds $\mathrm{Co}_{2} \mathrm{CrZ}$ ( $\left.\mathrm{Z}=\mathrm{In}, \mathrm{Sb}, \mathrm{Sn}\right) 3.11,5.00$ and $4.00 \mu_{\mathrm{B}}$ respectively. However, the respective magnetic moment of these compounds is found to be $3.14,5.05$ and $4.12 \mu_{\mathrm{B}}$ in ATK-VNL code. Calculated magnetic moments have good agreement with the Slater-Pauling behavior. Optical properties play an important role to understand the nature of material for optical phenomenon and optoelectronics devices. Value of absorption coefficient and optical conductivity of $\mathrm{Co}_{2} \mathrm{CrSb}$ is greatest than other two compounds. From the absorption and reflection spectra relation, observations indicate that absorption and reflectivity are inversely proportional to each other.

KEYWORDS: Half-metallic ferromagnetic, band gap, density of state, Spintronics

The history of Heusler compounds started in the year 1903 to 1912, when a German mining engineer and chemist Friedrich Heusler discovered a ferromagnetic material at room temperature. In those days that is major finding of Heusler. This ferromagnetic material is shaped by non magnetic element $\mathrm{Cu}, \mathrm{Mn}$ and $\mathrm{Al}$ at room temperature $[1,2,3]$. After that ferromagnetism is found in the materials, which are framed by $\mathrm{Cu}$ and $\mathrm{Mn}$ with $\mathrm{Z}$ position like $\mathrm{Sb}, \mathrm{Bi}$ and $\mathrm{Sn}$. But in the recent years, there are number of Heusler compounds framed, after the ideas of Louis Neel in the year 1930-1940s of antiferromagnetism and ferrimagnetism [4, 5]. In this paper we discuss the some properties of full Heusler compounds. These compounds are ternary compounds showing $\mathrm{L} 2{ }_{1}$ structure formed by three interpenetrating FCC-lattices. Chemical formula for Full Heusler compound is $\mathrm{X}_{2} \mathrm{YZ}$ and their composition is representing by 2:1:1 [6-9]. Half metallic ferromagnetic behavior of Heusler alloys was firstly predicted by de Groot in 1983 in semi-Heusler compound NiMnSb [10-11]. Along the passage of time half metallicity turns on more curiosity due to its precious spintronic application. Compounds exhibit $100 \%$ spin polarization, if either one spin channel shows band gap and other shows zero band gap at Fermi level [12-15]. Ishida et al. [16] have also put their results represent that the compounds $\mathrm{Co}_{2} \mathrm{MnZ}(\mathrm{Z}=\mathrm{Ge}, \mathrm{Sn})$ are semi metals and showing 100\% spin polarization. Galanakis et al. [17] have presented that in Full Heusler compounds $\mathrm{X}_{2} \mathrm{YZ}$ band gap occur due to the interaction in $\mathrm{d}$ orbital of $\mathrm{X}$ and $\mathrm{Y}$, which generate bonding and anti bonding state by a vent. Umetsu et al. [18] have investigated that $\mathrm{Co}_{2} \mathrm{CrGa}$ compound has a stable magnetic moment $3.01 \mu_{\mathrm{B}}$ at $4.2 \mathrm{k}$ and follow the Slater-Pauling rule $\mathrm{Zt}-24=$ total magnetic moment. Miura et al. [19] also studied that $\mathrm{Co}-$ based Full Heusler compounds shows the behavior of half - metallic ferromagnets. Seema et al. [20] shows by their investigation of electronic, magnetic and optical properties of $\mathrm{Co}_{2} \mathrm{CrZ}(\mathrm{Z}=\mathrm{Al}, \mathrm{Ga}, \mathrm{Ge}, \mathrm{Si})$ that there are three types of disorders, namely $\mathrm{DO}_{3}, \mathrm{~A} 2$ and $\mathrm{B} 2$. In these disorders $\mathrm{DO} 3$ and $\mathrm{A} 2$ disorder leads decrease in the spin polarization and $\mathrm{B} 2$ disorder retains the spin polarization at Fermi level.

In this paper, we have investigated the structural, electronic, optical and magnetic properties of $\mathrm{Co}_{2} \mathrm{CrZ}(\mathrm{Z}=\mathrm{In}$, $\mathrm{Sb}, \mathrm{Sn}$ ) compounds, by using WIEN2k code and Atomistic Tool Kit-Virtual NanoLab (ATK-VNL) code within Generalized-gradient approximation (GGA) for exchange correlation functions.

\section{COMPUTATION DETAILS}

An investigation of structural, electronic, optical and magnetic properties have been performed by full-potential linearized augmented plane wave (FP-LAPW) [21] method incorporated in Wien2k code [22]. For the calculation of lattice parameter and total energy, Generalized-gradient approximation (GGA) [23] of Perdew, Burke and Ernzerhof (PBE) [24] was approved as the exchange-correlation function. Spin orbit coupling effect was considered to perform all the calculations. Wien $2 \mathrm{k}$ is one of the most accurate methods for performing electronic structure calculations for solids. Core states are considered relativistically and valence states are considered as semi-relativistic way and energy between these two states was set -6.0Ry. In first Brillouin zone, we have used $1000 \mathrm{k}$-points for this code. But for the calculation of optical properties we need to increase the number of k-points and this increased value of k-points used are 10000 . The 
size of the basis sets are controlled by convergence or cutoff parameter, whose value is $\mathrm{R}_{\mathrm{mt}} \mathrm{K}_{\max }$ set to 7.0. Here plane wave radius is denoted by $R_{m t}$ and maximum modulus for reciprocal lattice vector is denoted by $K_{\max }$. The energy convergence criterion was taken as $0.0001 \mathrm{Ry}$. To expand the spherical harmonics in the atomic sphere the value of angular momentum maximum $\left(l_{\max }\right)$ is taken as 10 . In the central region the charge density and potential were elaborated as a cheerier series with wave vector up to $G_{\max }=10$. For the each atom muffin tin sphere radii ( $R_{M T}$ ) are tabulated in Table 1.

Table 1

Muffin tin radius $\left(\mathrm{R}_{\mathrm{MT}}\right)$ for $\mathrm{Co}_{2} \mathrm{CrZ}(\mathrm{Z}=\mathrm{In}, \mathrm{Sb}, \mathrm{Sn})$.

\begin{tabular}{|c|c|c|c|}
\hline \multirow{2}{*}{$\mathrm{R}_{\mathrm{MT}}$ (a.u.) } & \multicolumn{3}{|c|}{ Compounds } \\
\cline { 2 - 4 } & $\mathrm{Co}_{2} \mathrm{CrIn}$ & $\mathrm{Co}_{2} \mathrm{CrSb}$ & $\mathrm{Co}_{2} \mathrm{CrSn}$ \\
\hline $\mathrm{Co}$ & 2.35 & 2.37 & 2.43 \\
\hline $\mathrm{Cr}$ & 2.29 & 2.31 & 2.37 \\
\hline $\mathrm{Z}$ & 2.35 & 2.37 & 2.43 \\
\hline
\end{tabular}

Above mentioned properties are also investigated with the help of commercially licensed Atomistic Tool Kit-Virtual NanoLab (ATK-VNL) package [25]. Which is a Pseudo-potential method carried out in the framework of density functional theory (DFT) [26, 27]. First-principles calculations have been applied to investigate electronic and magnetic properties of $\mathrm{Co} 2 \mathrm{CrZ}(\mathrm{Z}=\mathrm{In}, \mathrm{Sb}, \mathrm{Sn})$ using Pulay Mixer algorithm [28]. For investigations, we have used double-zeta $(\zeta)$ polarized basis set for electron wave function expanding and GGA for exchange-correlation functional. The structures are permitted to optimize until each atom achieve force convergence criteria $0.05 \mathrm{eV} / \AA$ and maximum stress is 0.05 $\mathrm{eV} / \AA^{3}$. Optimization is performed in 200 maximum number of step and during this process maximum step size is also fixed i.e. $0.2 \AA$. Convergence is achieved by deciding mesh cutoff energy on the ground of convergence principle and for this computation 150 Ryd has been projected all over calculation as the most favorable after several convergence test. For spin polarization, up and down initial state have been selected for the atoms. We used 10 x 10 x 10 Monkhorst-Pack kmesh [29] for brillouin zone sampling to maintain balance between computational time and results accuracy. Further, all constrain in $\mathrm{x}, \mathrm{y}$ and $\mathrm{z}$ directions are removed for optimization of structures.

\section{RESULTS AND DISCUSSIONS Structural parameters}

Space group of full Heusler compound is $225 \mathrm{Fm}-3 \mathrm{~m}$. The chemical formula for full Heusler is $\mathrm{X}_{2} \mathrm{YZ}_{\mathrm{Z}}$ showing their composition 2:1:1. Its structure is formed by three penetrating FCC-lattices with atomic positions at $X_{1}(1 / 4,1 / 4,1 / 4)$, $\mathrm{X}_{2}(3 / 4,3 / 4,3 / 4), \mathrm{Y}(1 / 2,1 / 2,1 / 2)$ and $\mathrm{Z}(0,0,0)$. Where $\mathrm{X}$ and $\mathrm{Y}$ atoms are transition metal and $\mathrm{Z}$ is main group metal or semimetal $[30,31]$. The equation of state given by Murnaghan [32] gives the value of total energy \& pressure as a function of volume is stated as:

$$
\begin{gathered}
E(V)=E_{O}+\left[\frac{B V}{B_{P}}\left(\frac{1}{\left(B_{P}-1\right)}\left(\frac{V_{O}}{V}\right)^{B_{P}}+1\right)-\frac{B V_{O}}{\left(B_{P}-1\right)}\right] \\
P(V)=\frac{B}{B_{P}}\left\{\left(\frac{V_{O}}{V}\right)^{B_{P}}-1\right\},
\end{gathered}
$$

where, Pressure $(P)=-\frac{d E}{d V}, B_{P}=-V \frac{d P}{d V}=V \frac{d^{2} E}{d V^{2}}$

In the above equations $\mathrm{E}_{0}$ is the minimum energy at $\mathrm{T}=0 \mathrm{~K}, \mathrm{~B}$ is the bulk modulus, $\mathrm{B}_{\mathrm{P}}$ is the pressure derivative of the bulk modulus and $\mathrm{V}_{\mathrm{o}}$ is the equilibrium volume. For structure optimization we have used volume optimization and their results are shown in Figure 1. There are slight differences between the optimized lattice parameter of WIEN2k and ATK lattice parameters. Optimized lattice parameters in WIEN2k for $\mathrm{Co}_{2} \mathrm{CrIn}$ and $\mathrm{Co}_{2} \mathrm{CrSn}$ are slightly greater than the lattice parameters optimized in ATK-VNL, where $\mathrm{Co}_{2} \mathrm{CrSb}$ has slightly less value in WIEN2k. If we compare the values of bulk modulus by WIEN2k and ATK-VNL then results obtained by WIEN2k are greater to the ATK-VNL. The compound $\mathrm{Co}_{2} \mathrm{CrSn}$ has showing largest value of bulk modulus in comparison to the others. Calculated values of the optimized lattice parameter, equilibrium energy and pressure derivative have been representing in Table 2.

Table 2.

Lattice parameter, Bulk modulus, Equilibrium energy and Pressure derivative for $\mathrm{Co}_{2} \mathrm{CrZ}(\mathrm{Z}=\mathrm{In}, \mathrm{Sb}, \mathrm{Sn})$

\begin{tabular}{|c|c|c|c|c|c|c|}
\hline \multirow{2}{*}{ Compound } & \multicolumn{2}{|c|}{ Lattice Constants $\mathrm{a}_{0}(\AA)$} & \multicolumn{2}{c|}{ Bulk modulus (GPa) } & \multirow{2}{*}{$\begin{array}{c}\text { Equilibrium } \\
\text { Energy (Ry) }\end{array}$} & $\begin{array}{c}\text { Pressure } \\
\text { derivative (GPa) }\end{array}$ \\
\cline { 2 - 5 } & \multicolumn{2}{|c|}{ Calculated } & \multicolumn{2}{c|}{ Calculated } & & \\
\cline { 2 - 5 } & WIEN2k & ATK & WIEN2k & ATK & & 1.399 \\
\hline $\mathrm{Co}_{2} \mathrm{CrIn}$ & 5.962 & 5.957 & 229.40 & 167.16 & -19442.157 & 3.956 \\
\hline $\mathrm{Co}_{2} \mathrm{CrSb}$ & 6.014 & 6.044 & 180.15 & 178.43 & -20642.889 & -12.017 \\
\hline $\mathrm{Co}_{2} \mathrm{CrSn}$ & 5.984 & 5.957 & 348.57 & 208.84 & -20033.879 & \\
\hline
\end{tabular}



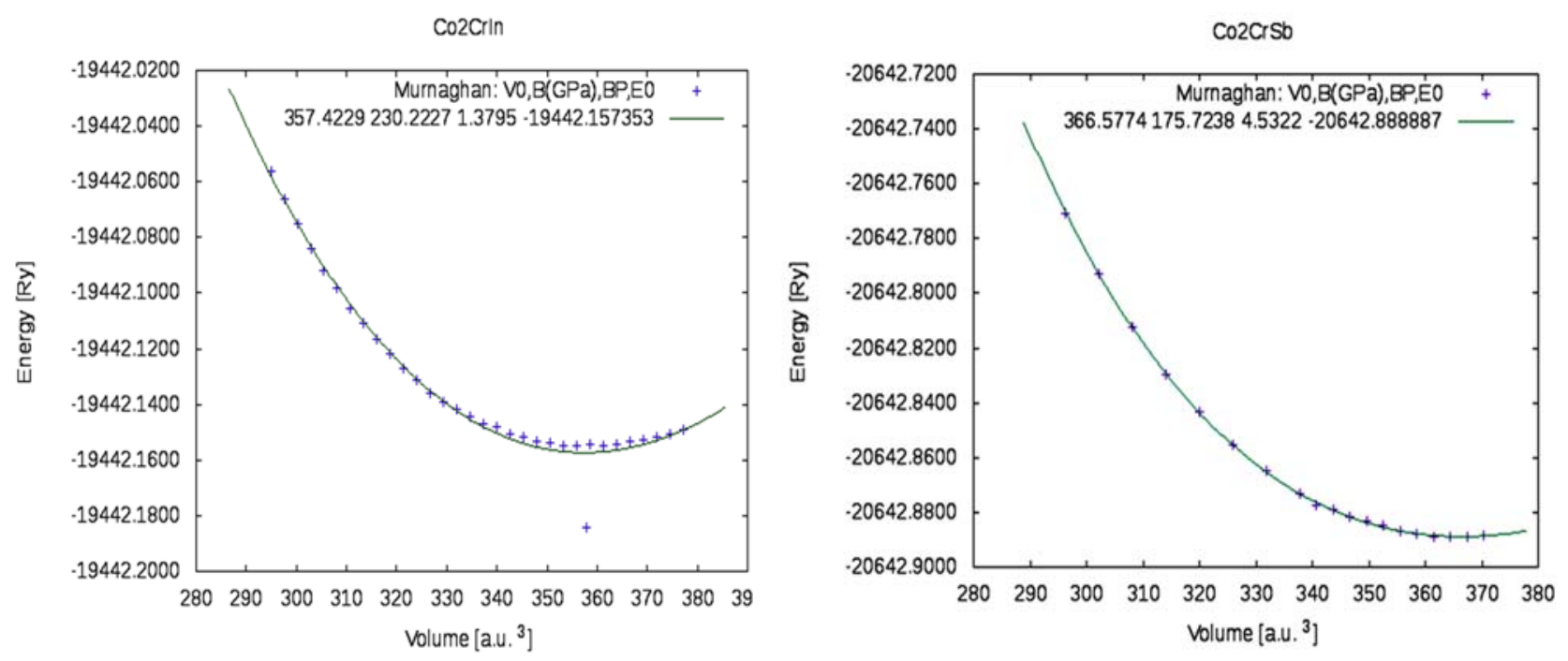

$\mathrm{Co2CrSn}$

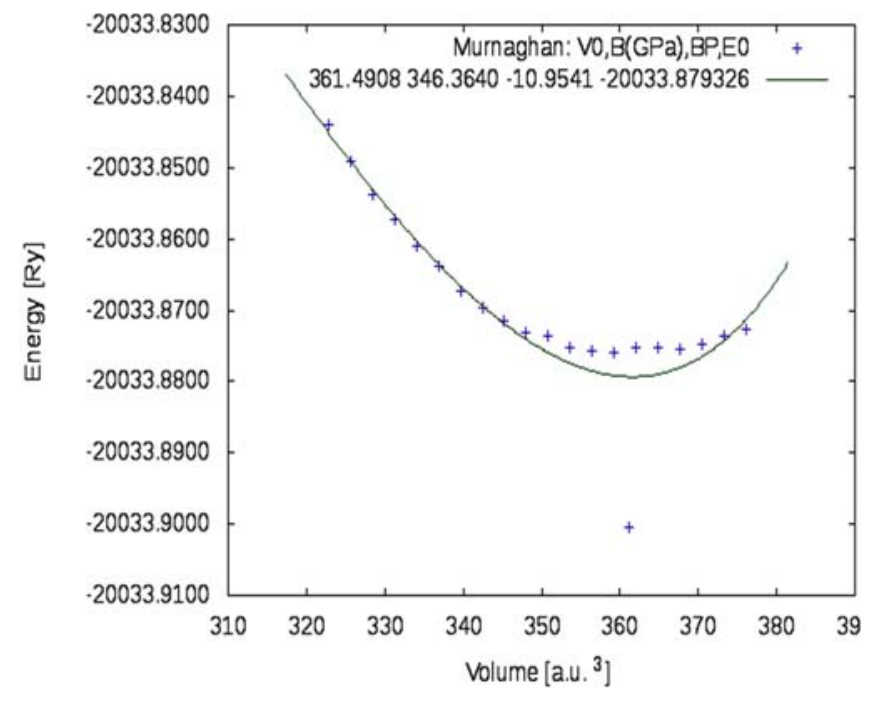

Figure 1. Volume optimization for the lattice parameters

\section{Electronic and magnetic properties}

In the present era Spintronics is very useful ground work, which is very innovative for future technology. The advantages of Spintronics devices are nonvolatile memory and high processing speed of data. These devices consume less electric power and their heat dissipation is also decrease. Half-metallic ferromagnets having 100\% spin-polarized can optimize the accomplishment of these devices. Spin polarized calculations of $\mathrm{Co}_{2} \mathrm{CrZ}(\mathrm{Z}=\mathrm{In}, \mathrm{Sb}, \mathrm{Sn})$ compounds within Generalized-gradient approximation (GGA) full Heusler have been carried out at the optimized lattice parameters. If band structure shows zero band gaps in majority spin channel and a band gap in minority spin channel then the compound shows $100 \%$ spin polarization at Fermi level. Intrinsic spin of electron is also responsible for magnetic moment. Theoretical calculations of spin polarization can be done using the formula as given below.

$$
\mathrm{P}_{\mathrm{n}}=\frac{\mathrm{n} \uparrow-\mathrm{n} \downarrow}{\mathrm{n} \uparrow+\mathrm{n} \downarrow} .
$$

If either $\mathrm{n}_{\uparrow}=0$ or $\mathrm{n}_{\downarrow}=0$, then $\mathrm{P}_{\mathrm{n}}=1$ or -1 . It means, if either only one spin channel is existing then the spin polarization is $100 \%$. These types of materials are known as half metals ferromagnetic. If the value of $P_{n}$ is vanishes then the materials are paramagnetic or anti-ferromagnetic even below the magnetic transition temperature [33]. After studying the energy gag from DOS and band structure of the compounds $\mathrm{Co}_{2} \mathrm{CrZ}$ ( $\mathrm{Z}=\mathrm{In}, \mathrm{Sb}, \mathrm{Sn}$ ), we have concluded that out of three compounds only $\mathrm{Co}_{2} \mathrm{CrSb}$ show a band gap in minority spin with value $0.54 \mathrm{eV}$ in WIEN2k code, showing $100 \%$ spin polarization. Other two listed compounds show zero band gaps, showing metallic behavior. Outcome of ATK-VNL code revels that all three compounds show metallic behavior. Obtained energy gap and spin polarization for the above approximation is summarized as under in Table 3. The detailed results of band structures and density of states are shown in Figures 2-5. 
Table 3.

Energy gap and spin polarization for $\mathrm{Co}_{2} \mathrm{CrZ}(\mathrm{Z}=\mathrm{In}, \mathrm{Sb}, \mathrm{Sn})$.

\begin{tabular}{|c|c|c|c|c|c|c|}
\hline \multirow{2}{*}{ Compound } & \multicolumn{4}{|c|}{ Energy gap $E_{\mathrm{g}}(\mathrm{eV})$} & \multicolumn{2}{c|}{ Spin polarization } \\
\cline { 2 - 7 } & \multicolumn{2}{|c|}{ WIEN2k } & \multicolumn{2}{c|}{ ATK } & \multirow{2}{*}{ WIEN2k } & ATK \\
\cline { 2 - 7 } & Up spin & Down spin & Up spin & Down spin & & \\
\hline Co2CrIn & 0.0 & 0.0 & 0.0 & 0.0 & $P_{\mathrm{n}}$ vanishing & $\mathrm{P}_{\mathrm{n}}$ vanishing \\
\hline $\mathrm{Co} 2 \mathrm{CrSb}$ & 0.0 & 0.54 & 0.0 & 0.0 & $100 \%$ & $\mathrm{P}_{\mathrm{n}}$ vanishing \\
\hline $\mathrm{Co} 2 \mathrm{CrSn}$ & 0.0 & 0.0 & 0.0 & 0.0 & $\mathrm{P}_{\mathrm{n}}$ vanishing & $\mathrm{P}_{\mathrm{n}}$ vanishing \\
\hline
\end{tabular}
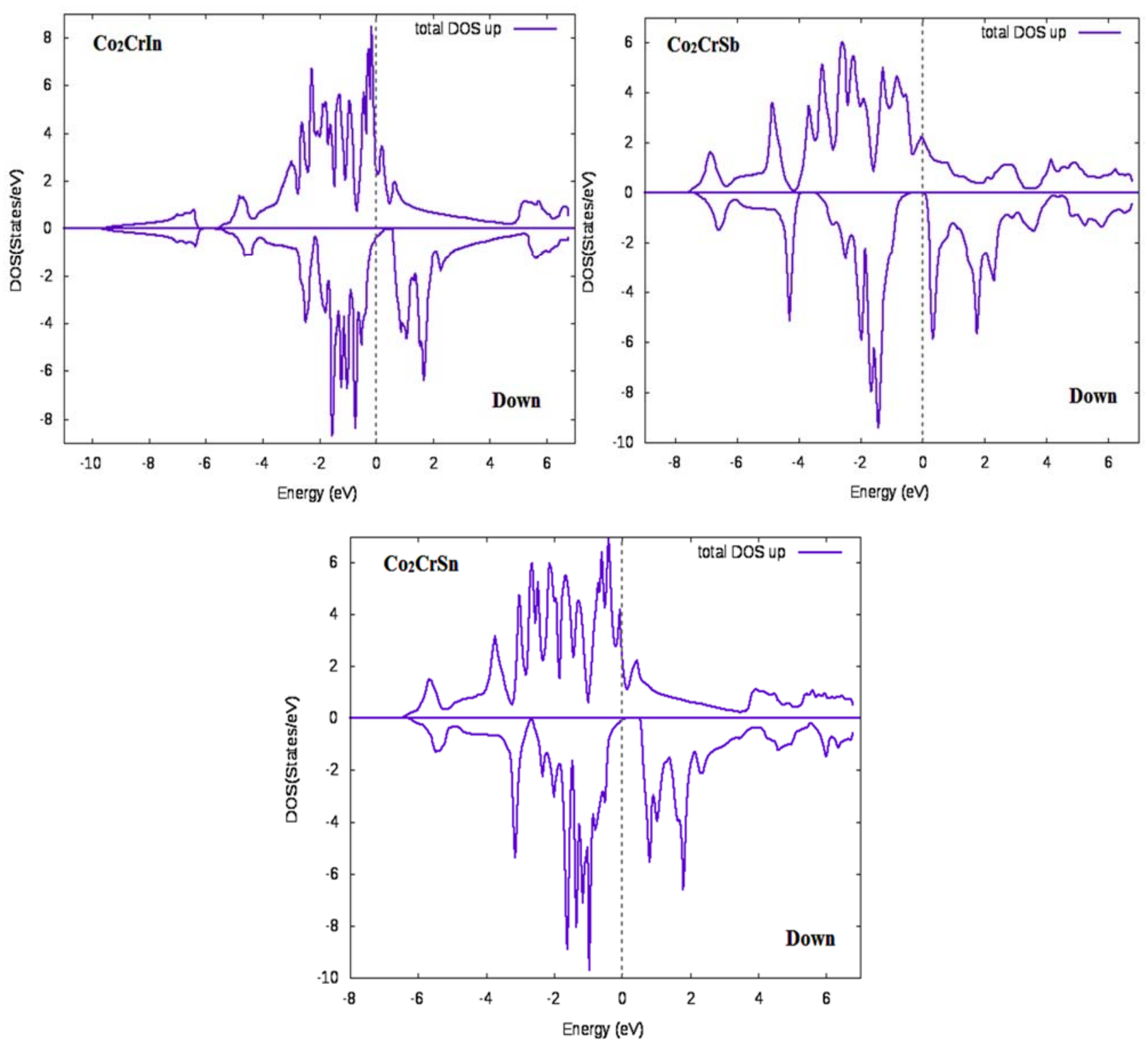

Figure 2. DOS of $\mathrm{Co}_{2} \mathrm{CrZ}(\mathrm{Z}=\mathrm{In}, \mathrm{Sb}, \mathrm{Sn})$ using WIEN2K Code

Total valence electron count can propose the result of magnetic moment per unit cell of Heusler compounds. This theoretical method of prediction of magnetic moment is provided by Slater-Pauling. Method for Full Heusler compound is as given by

$$
\mathrm{M}_{\mathrm{t}}=\mathrm{Z}_{\mathrm{t}}-24
$$

where, $M_{t}$ denotes the total magnetic moment per unit cell and $Z_{t}$ denotes the total count of valence electron [33,34]. 

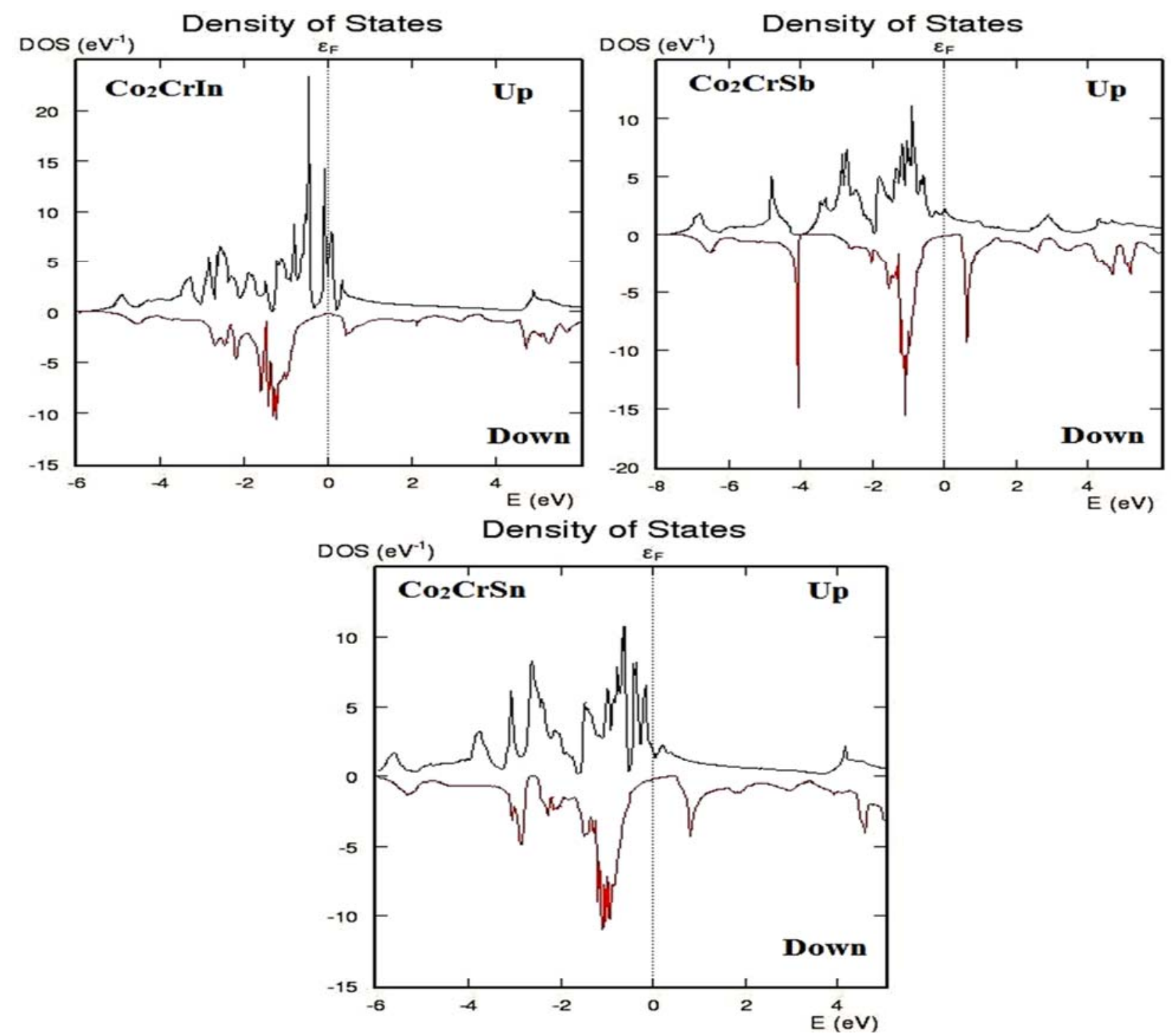

Figure 3. DOS of $\mathrm{Co}_{2} \mathrm{CrZ}(\mathrm{Z}=\mathrm{In}, \mathrm{Sb}, \mathrm{Sn})$ using ATK-VNL Code
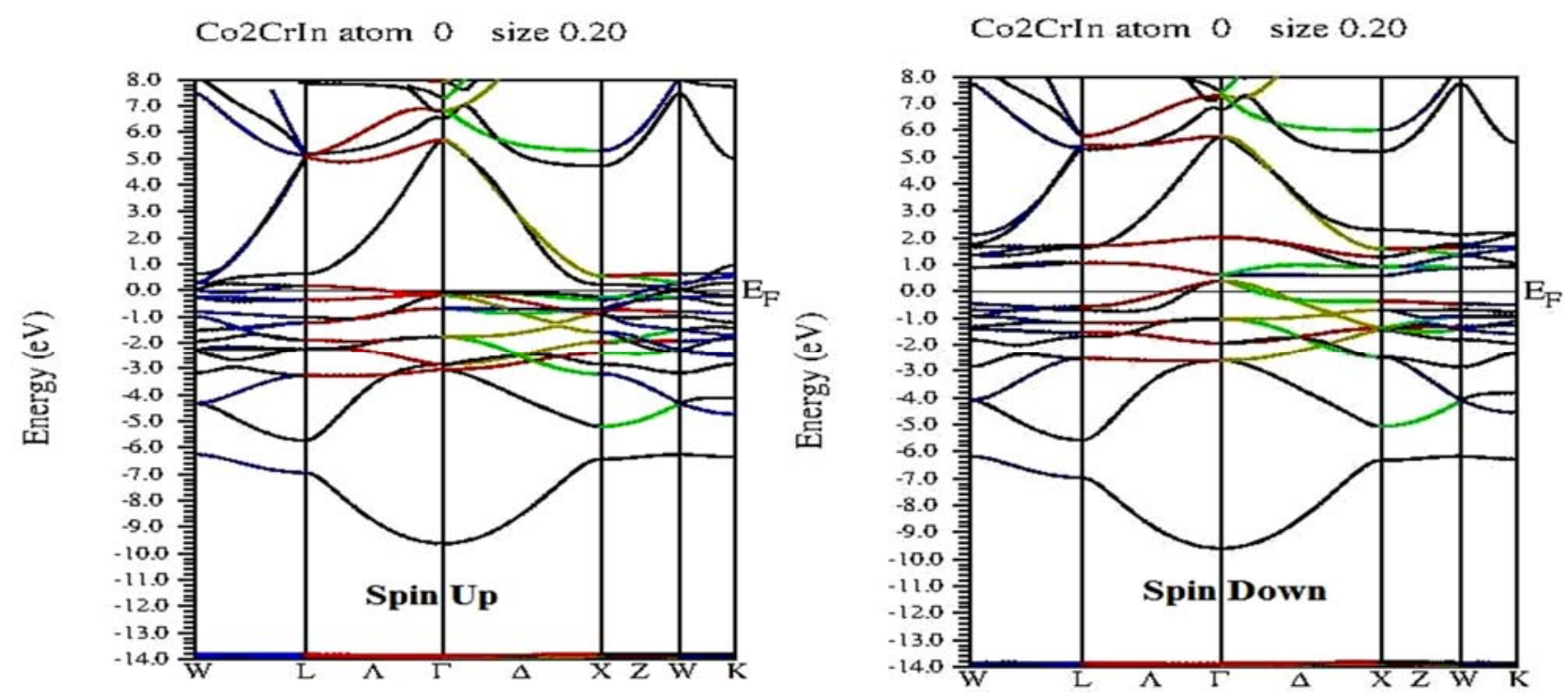

Figure 4. Band Structure of $\mathrm{Co}_{2} \mathrm{CrZ}(\mathrm{Z}=\mathrm{In}, \mathrm{Sb}, \mathrm{Sn})$ using WIEN2K Code (Continied on next page) 

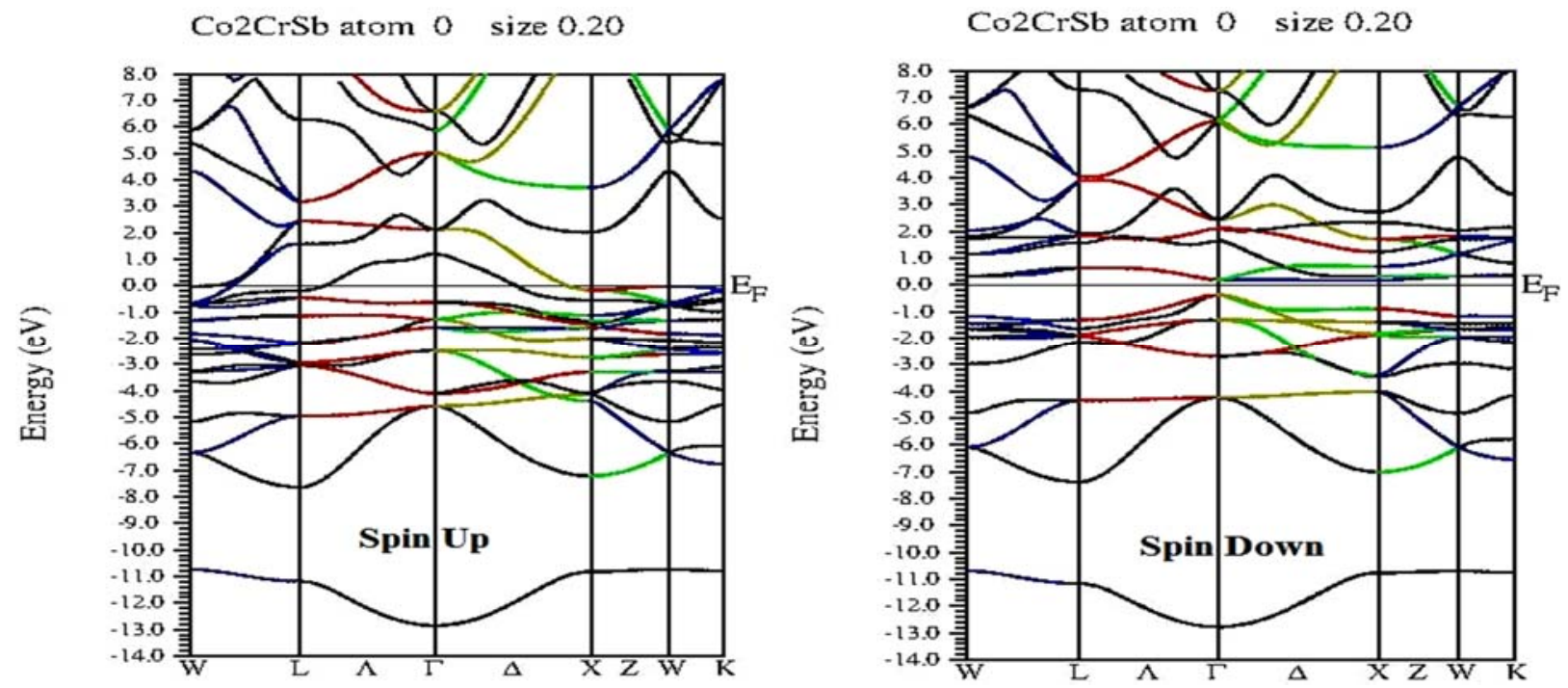

Co2CrSn atom o size 0.20

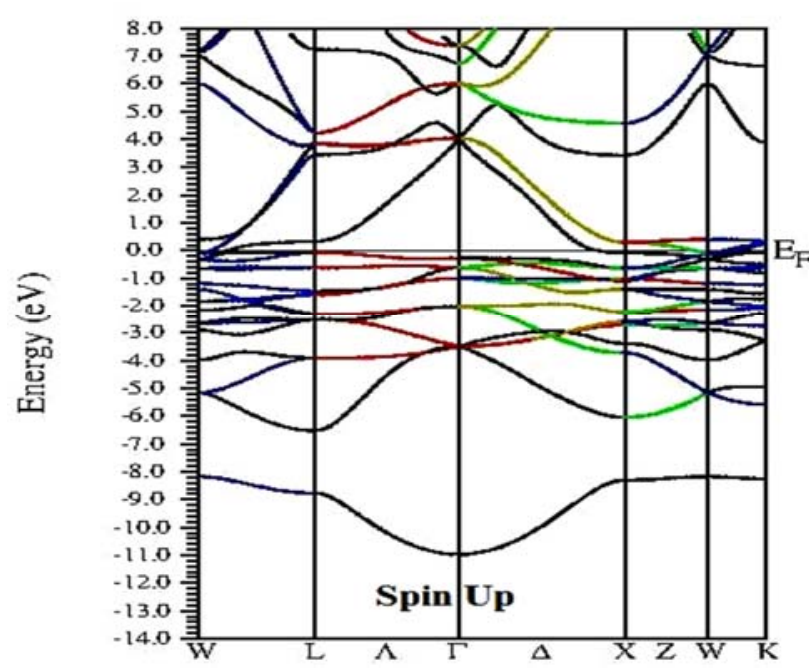

$\mathrm{Co} 2 \mathrm{CrSn}$ atom $\mathrm{O}$ size 0.20

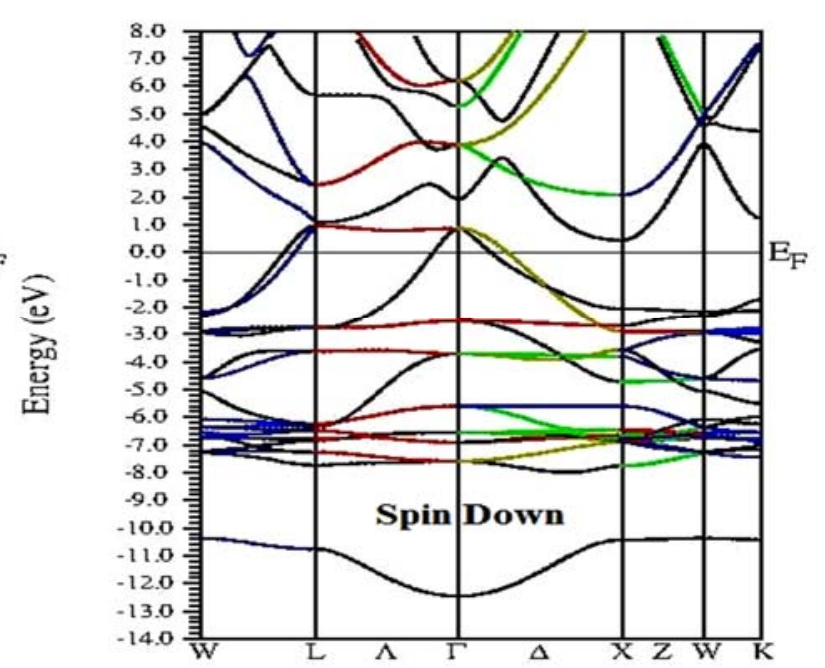

Figure 4. Band Structure of $\mathrm{Co}_{2} \mathrm{CrZ}(\mathrm{Z}=\mathrm{In}, \mathrm{Sb}, \mathrm{Sn})$ using WIEN2K Code (Continiation)
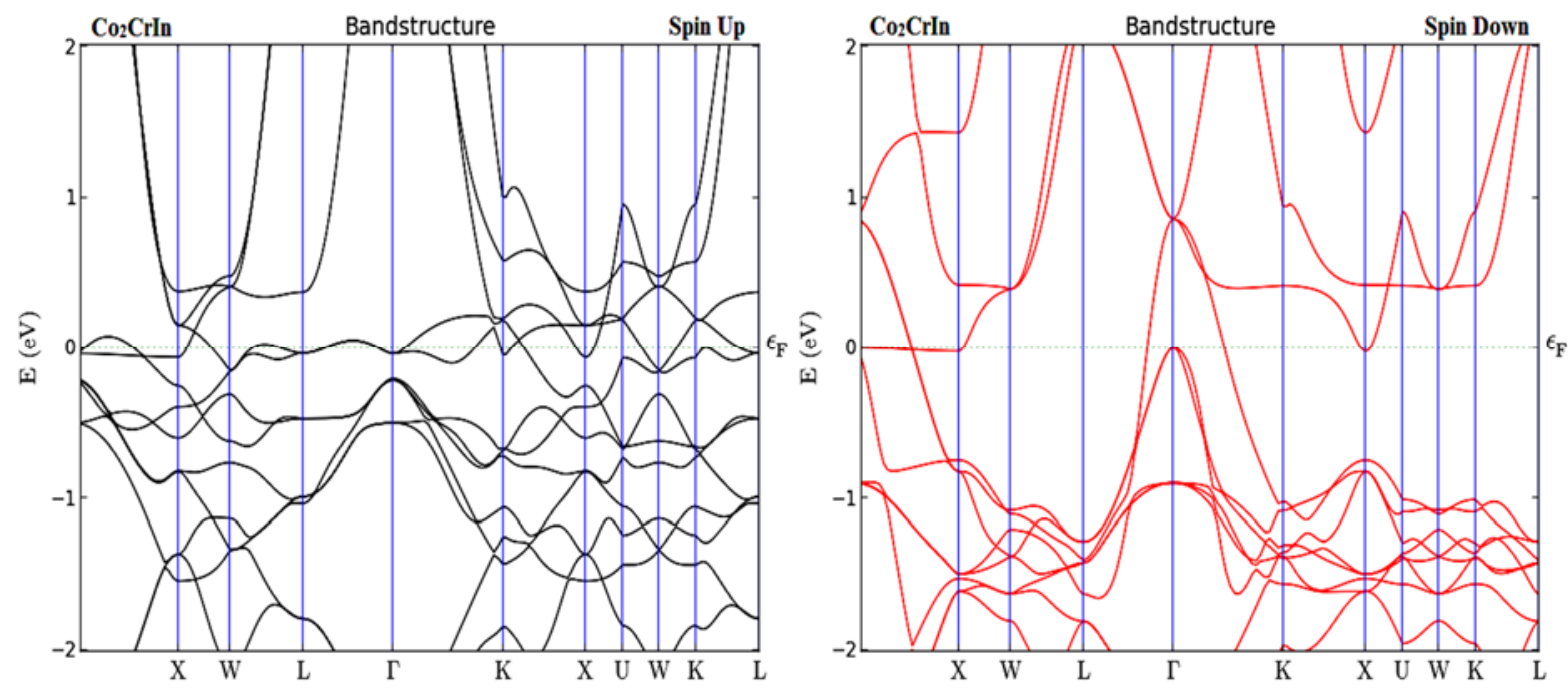

Figure 5. Band Structure of $\mathrm{Co}_{2} \mathrm{CrZ}(\mathrm{Z}=\mathrm{In}, \mathrm{Sb}, \mathrm{Sn})$ using ATK-VNL Code (Continied on next page) 

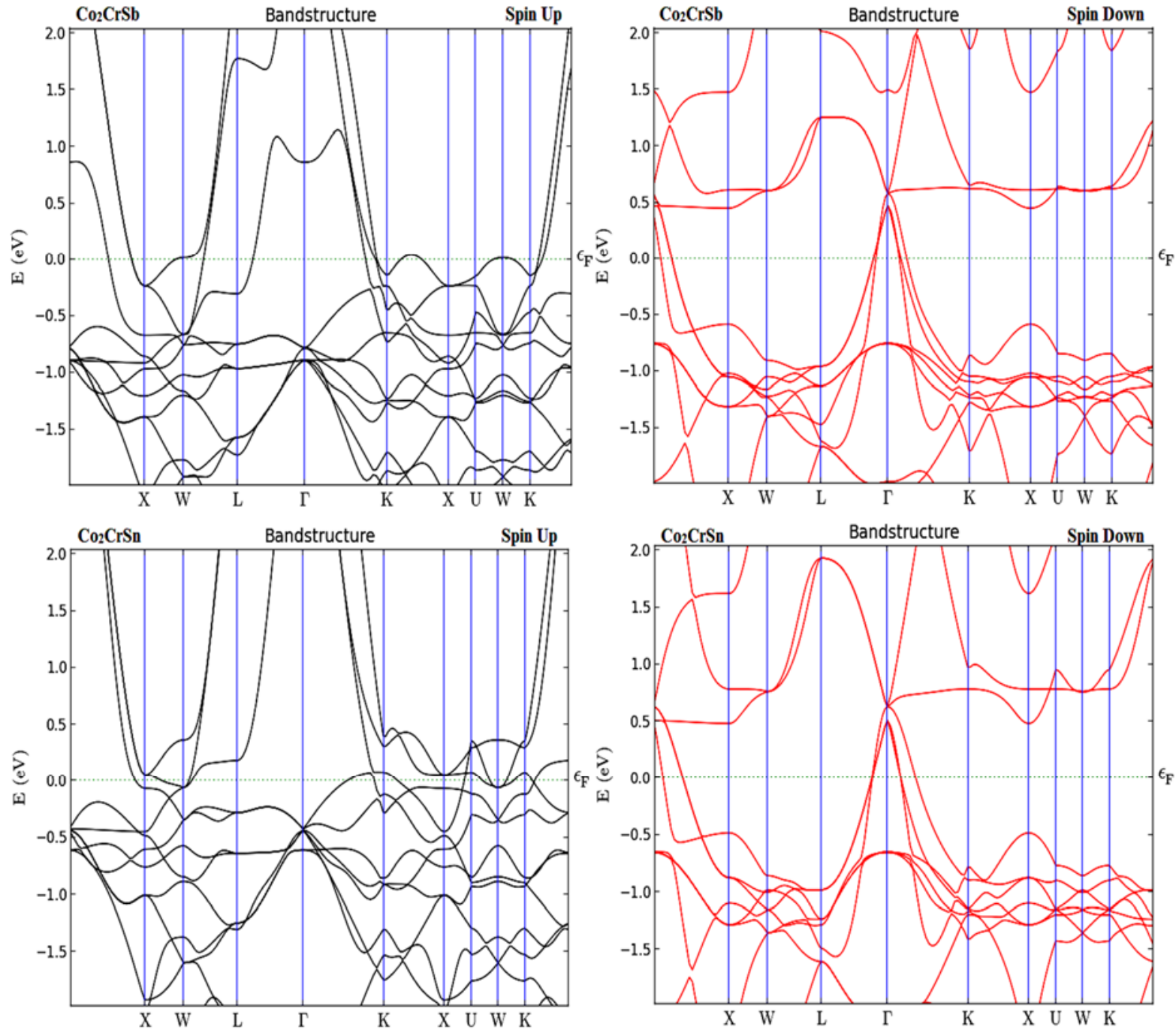

Figure 5. Band Structure of $\mathrm{Co}_{2} \mathrm{CrZ}(\mathrm{Z}=\mathrm{In}, \mathrm{Sb}, \mathrm{Sn})$ using ATK-VNL Code

(Continiation)

Here, we have compared the values by the codes WIEN2k and ATK-VNL with derived from theoretical method Slater-Pauling. If obtained results are equivalent to Slater-Pauling result then we can say that it follow the Slater-Pauling behavior. From the Table 4, we can easily analysis the values of WIEN2k, ATK-VNL code and Slater-Pauling rule. Total number of valence electron of $\mathrm{Co}_{2} \mathrm{CrZ}(Z=\mathrm{In}, \mathrm{Sb}, \mathrm{Sn})$ alloys are 27, 29 and 28 respectively. So there magnetic moments per unit cell are 3.0, 5.0 and $4.0 \mu_{\mathrm{B}}$ respectively from Slater-Pauling rule. Now, the results compiled by WIEN2k and ATK-VNL are 3.11 and 3.14, 5.00 and 5.05, 4.00 and 4.12 respectively. These compiled values are equivalent to values of theoretical method Slater-Pauling. So, these listed compounds have nice agreement with Slater-Pauling behavior. Investigation of results revels that $\mathrm{Co}$ and $\mathrm{Cr}$ position atom contribute major section of magnetic moment and small amount of magnetic moment contribution is due to $\mathrm{Z}$ position atom. It was also observed that more amount of magnetic moment at sites $\mathrm{Co}$ and $\mathrm{Cr}$ are induces as $\mathrm{Z}$ atom have more valence electron. The calculated results for magnetic moments for $\mathrm{Co} 2 \mathrm{CrZ}$ ( $\mathrm{Z}=\mathrm{In}, \mathrm{Sb}, \mathrm{Sn}$ ) obtained using full potential linearized augmented plane wave (FP-LAPW) method implemented in WIEN2k and pseudo-potentials method implemented in Atomistic Tool Kit-Virtual NanoLab (ATK-VNL) within Generalized- gradient approximation (GGA) for exchange correlation functions is tabulated in Table 4.

Table 4.

Total magnetic moments of the compounds $\mathrm{Co}_{2} \mathrm{CrZ}(\mathrm{Z}=\mathrm{In}, \mathrm{Sb}, \mathrm{Sn})$.

\begin{tabular}{|c|c|c|c|c|}
\hline \multirow{2}{*}{ Compounds } & \multirow{2}{*}{$Z_{\mathrm{t}}$} & \multicolumn{3}{|c|}{ Magnetic moment $\left(\mu_{\mathrm{B}}\right)$} \\
\cline { 3 - 5 } & & WIEN2k & ATK & $\begin{array}{c}\text { Slater-Pauling } \\
\left(Z_{\mathrm{t}}-24\right)\end{array}$ \\
\hline $\mathrm{Co}_{2} \mathrm{CrIn}$ & 27 & 3.11 & 3.14 & 3.00 \\
\hline $\mathrm{Co}_{2} \mathrm{CrSb}$ & 29 & 5.00 & 5.05 & 5.00 \\
\hline $\mathrm{Co}_{2} \mathrm{CrSn}$ & 28 & 4.00 & 4.12 & 4.00 \\
\hline
\end{tabular}




\section{Optical properties}

Optical properties play an important role to understand the nature of material; whether it can be used as optoelectronics device. The present section describes the optical properties of the compounds $\mathrm{Co}_{2} \mathrm{CrZ}(\mathrm{Z}=\mathrm{In}, \mathrm{Sb}, \mathrm{Sn})$. For the optical properties, we calculate the dielectric function, optical conductivity, reflectivity, excitation coefficient, absorption coefficient and electron energy loss as a function of photon energy for the above compounds. The complex dielectric function describes the optical response of a material on incident electromagnetic radiation.

$$
\varepsilon(\mathrm{m})=\varepsilon_{1}(\mathrm{~m})+\mathrm{i} \varepsilon_{2}(\mathrm{~m})
$$

Where $\varepsilon_{1}(\mathrm{~m})$ real represents polarization and anomalous dispersion of medium and $\mathrm{i} \varepsilon_{2}(\mathrm{~m})$ corresponds imaginary part represents the absorption or loss of energy into the medium [35, 36]. It is considered that the transitions exists from occupied to unoccupied bands for explain the optical spectra. Inter-band region is chosen for studying the optical properties. The different optical spectra are shown in Figure 6.
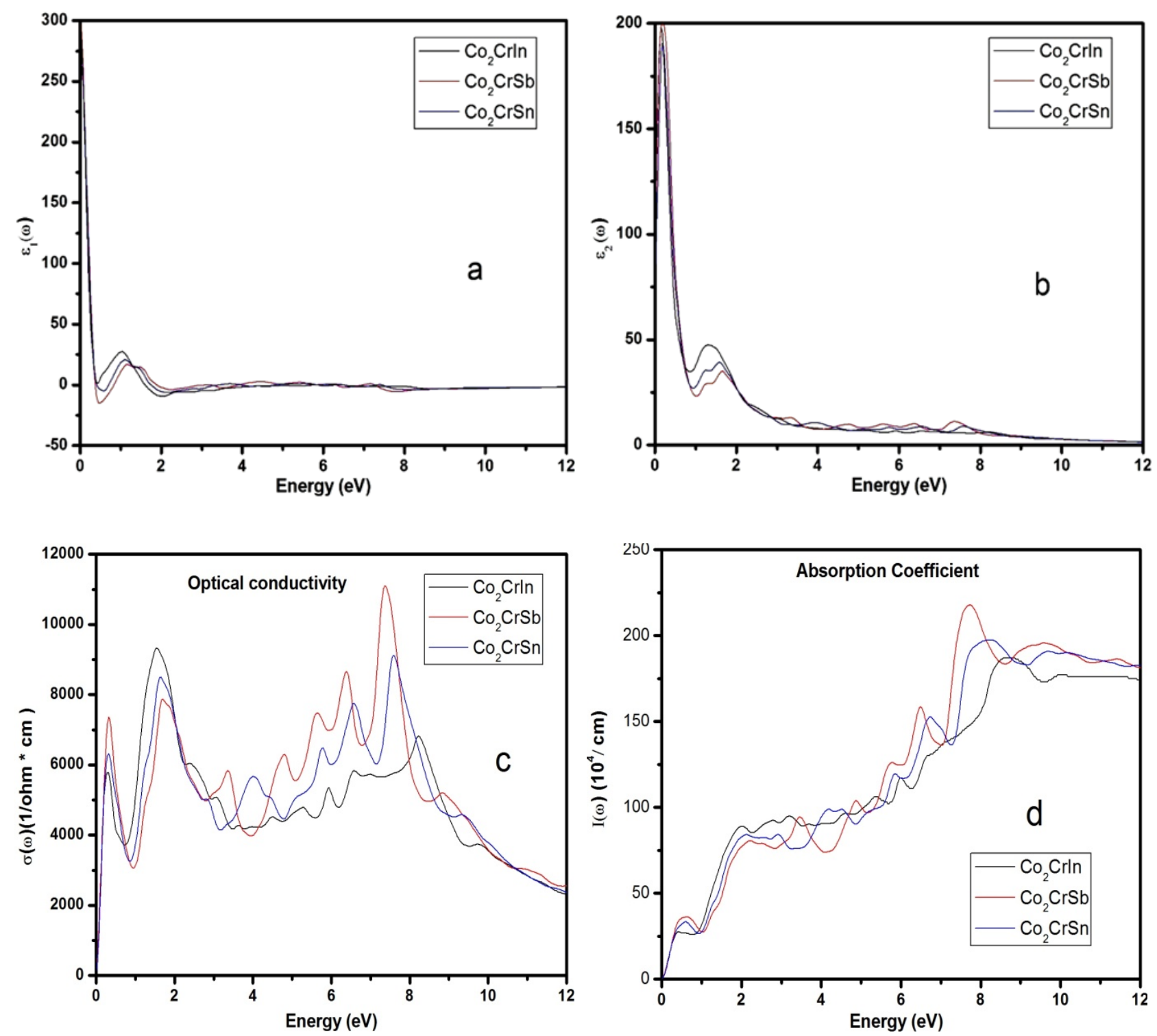

Figure 6. Calculated optical parameters (a) real part of dielectric function, (b) imaginary part of dielectric function, (c) optical conductivity, (d) absorption coefficient, (e) electron energy-loss function, (f) reflectivity, (g) refractive index and (h) extinction coefficient for $\mathrm{Co}_{2} \mathrm{CrZ}(\mathrm{Z}=\mathrm{In}, \mathrm{Sb}, \mathrm{Sn})$.

(Continued on next page)

The imaginary part of dielectric function for all three compounds shows the main peak in infrared region from 0.08 to $0.31 \mathrm{eV}$. After that, imaginary part of dielectric function decreases continuously and some small peaks are observed in infrared region, near visible region between $1.13-1.86 \mathrm{eV}$. The zero frequency real $\left(\varepsilon_{1}(\omega)\right)$ and imaginary part of complex dielectric functions values are 283.54 and $112.766,297.748$ and $120.002,265.679$ and 86.053 for the compounds Co2CrZ 
$(\mathrm{Z}=\mathrm{In}, \mathrm{Sb}, \mathrm{Sn})$ respectively as observed from the Figure 6 (a) and 6 (b). Optical conductivity is an important optical parameter for conduction of electron due to an applied electromagnetic field. In the optical conductivity spectrum, sharp peaks are observed at 0.18 to $0.50 \mathrm{eV}, 1.38$ to $1.88 \mathrm{eV}$ in infrared region and in ultraviolet region between $3.97-8.37 \mathrm{eV}$. A sharp peak is observed at $7.39 \mathrm{eV}$ by $\mathrm{Co}_{2} \mathrm{CrSb}$ showing largest conduction of electron. High absorption coefficient means that the material absorbs more photon, which excite electron from valence band to conduction band. The values of absorption coefficient are an increase along the values of energy is increases towards visible region to ultraviolet region as shown in the Figure 6(d).
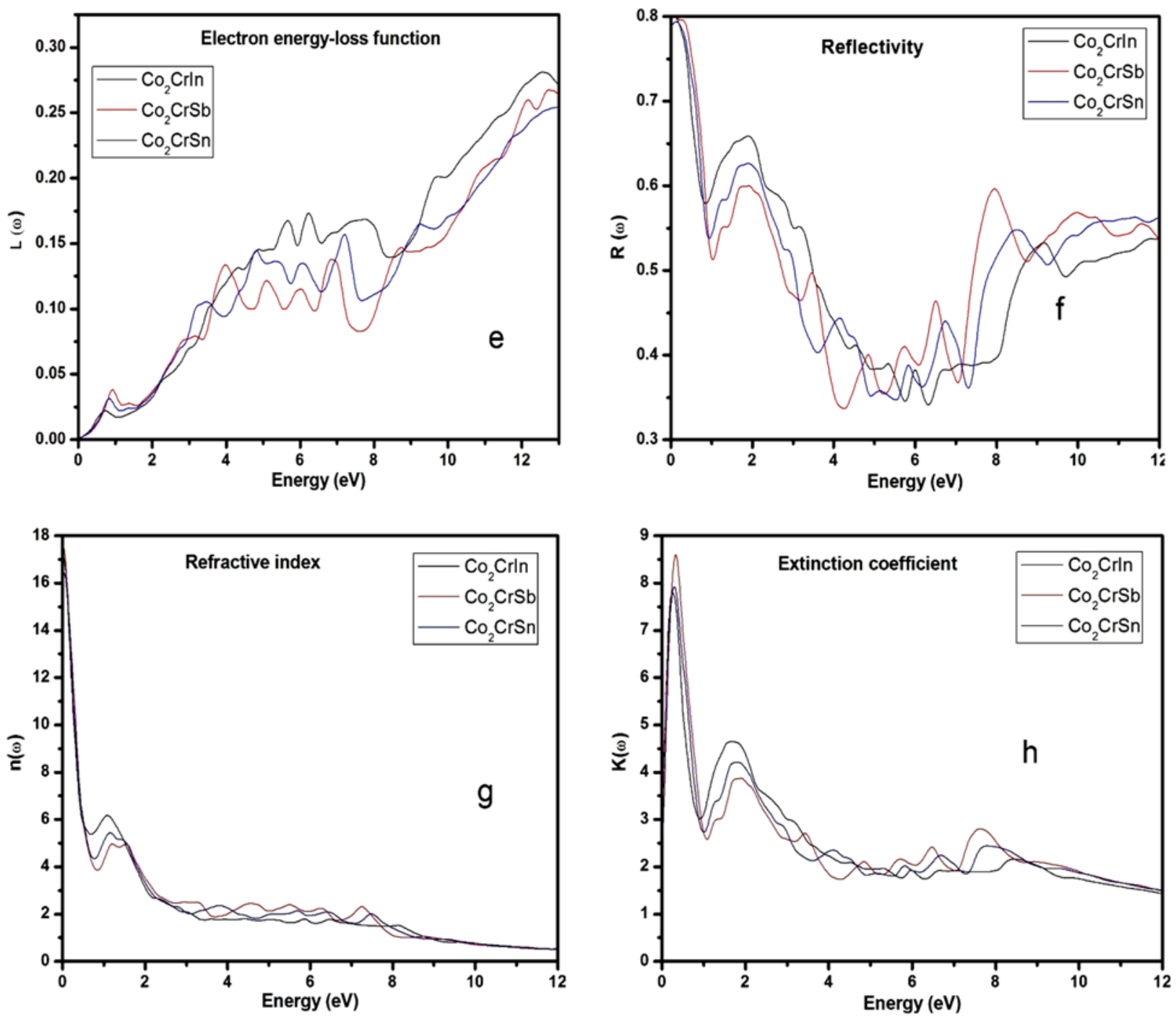

Figure 6. Calculated optical parameters (a) real part of dielectric function, (b) imaginary part of dielectric function, (c) optical conductivity, (d) absorption coefficient, (e) electron energy-loss function, (f) reflectivity, (g) refractive index and (h) extinction coefficient for $\mathrm{Co}_{2} \mathrm{CrZ}(\mathrm{Z}=\mathrm{In}, \mathrm{Sb}, \mathrm{Sn})$.

(Continuation)

Highest peaks are observed between $7.50-8.75 \mathrm{eV}$ by all above compounds. At $7.74 \mathrm{eV} \mathrm{Co}_{2} \mathrm{CrSb}$ showing highest peak out of three compounds representing maximum absorption of photons. Electron energy-loss function gives the energy loss of a fast moving electron when passing through the medium. The plasma frequency is the frequency corresponding to plasma resonance at which sharp peaks are associated. As if the frequency is above the plasma frequency then the material showing the dielectric behavior and below which the material shows metallic behavior. Value energy loss of fast moving electron is increases as move from infrared to ultraviolet region. The maximum energy loss is observed between 12 to $13 \mathrm{eV}$ for above these compounds as shown in Figure 6(e). An extinction coefficient spectrum is displayed in Figure $6(\mathrm{~h})$. A prominent narrow peak is shown in the infrared region along the range 0.20 to $0.46 \mathrm{eV}$ and then value of extinction coefficient is decreases. Near to visible region further a small peak is observed between $1.16-2.17 \mathrm{eV}$ and further value is decreases in the ultraviolet region with small peak near $8 \mathrm{eV}$. The values of zero frequency reflectivity are 0.798, 0.803 and 0.789 for the compounds $\mathrm{Co}_{2} \mathrm{CrZ}(\mathrm{Z}=\mathrm{In}, \mathrm{Sb}, \mathrm{Sn})$ respectively as observed from Figure 6 (f). From the absorption and reflection spectra relation, observations indicate that absorption and reflectivity are inversely proportional to each other. Value of reflectivity first decreases showing small peak near $2 \mathrm{eV}$ with the increase of energy up to $5.5 \mathrm{eV}$ 
and after that increases up to $8.3 \mathrm{eV}$ in the ultraviolet region. The region in which material substantially absorbs light and it cannot effectively reflect light in the same span. The refractive index is the important optical property due to wide applications because it determines the dispersive power of prisms, focusing power of lenses, light guiding, and critical angle for total internal reflection etc. How fast light is traveling through the materials is described by refractive index. The values for zero frequency refractive index for the compounds $\mathrm{Co}_{2} \mathrm{CrZ}(\mathrm{Z}=\mathrm{In}, \mathrm{Sb}, \mathrm{Sn})$ are observed as 17.156, 17.589 and 16.507 respectively.

\section{SUMMARY AND CONCLUSIONS}

Here, we have investigated structural, electronic, optical and magnetic properties of $\mathrm{Co}_{2} \mathrm{CrZ}(\mathrm{Z}=\mathrm{In}, \mathrm{Sb}, \mathrm{Sn})$. These properties have been studied by using full potential linearized augmented plane wave (FP-LAPW) method implemented in WIEN2k and pseudo- potentials method implemented in Atomistic Tool Kit-Virtual NanoLab (ATK-VNL) within Generalized-gradient approximation (GGA) for exchange-correlation functional. From study of DOS and band structure, we have clearly mentioned that the compound $\mathrm{Co}_{2} \mathrm{CrSb}$ is half metallic and $100 \%$ spin polarization with $\mathrm{L} 2_{1}$ ordered stable structures in WIEN2k code. Other two compounds show the metallic behavior with zero band gaps at Fermi level. Calculated magnetic moments have good agreement with the Slater-Pauling behavior. For above listed compounds, the optical properties named as reflectivity, refractive index, excitation coefficient, absorption coefficient, optical conductivity and electron energy loss have been calculated. Also, we have analyzed their optical spectra and Inter-band region is chosen for studying the optical properties. Value of absorption coefficient and optical conductivity of $\mathrm{Co}_{2} \mathrm{CrSb}$ is greatest than other two compounds.

\section{ORCID IDs}

CSukhender, https://orcid.org/0000-0002-2149-5669; -Lalit Mohan, https://orcid.org/0000-0003-3323-8296

(-Pravesh Pravesh, https://orcid.org/0000-0002-0876-4836; (D)Ajay Singh Verma, https://orcid.org/0000-0001-8223-7658

\section{REFERENCES}

[1] Fr. Heusler, Ueber magnetische Manganlegierungen. Verh. Dtsch. Phys. Ges. 5, 219 (1903).

[2] Fr. Heusler, W. Starck, and E. Haupt, Magnetisch-Chemische Studien. Verh. Dtsch. Phys. Ges. 5, 220 (1903)

[3] Fr. Heusler, and E. Take, The nature of the Heusler alloys, Trans. Faraday Soc. 8, 169-184 (1912).

[4] L. Néel, Ann. de Phys. 5, 232-279 (1936), https://doi.org/10.1051/anphys/193611050232.

[5] L. Néel, Rev. Mod. Phys. 25 58-63 (1953), https://doi.org/10.1103/RevModPhys.25.58.

[6] I. Galanakis, in: Heusler Alloys. Properties, Growth, Applications, edited by C. Felser, and A. Hirohata (Springer International Publishing, Switzerland, 2016), pp. 3-36, https://doi.org/10.1007/978-3-319-21449-8.

[7] C.J. Palmstrom, Prog. Crys. Growth. Char. Mater. 62, 371-397 (2016), https://doi.org/10.1016/j.pcrysgrow.2016.04.020.

[8] A.O. Oliynyk, E. Antono, T.D. Sparks, L. Ghadbeigi, M.W. Gaultois, B. Meredig, and A. Mar, Chem. Mater. 28, 7324-7331 2016), https://doi.org/10.1021/acs.chemmater.6b02724.

[9] Arash Anjami, Arash Boochani, Seyed Moahammad Elahi, Hossein Akbari, Results Phys. 7, 3522-3529 (2017), https://doi.org/10.1016/j.rinp.2017.09.008.

[10] R.A. de Groot, F.M. Muller, P.G. van Engen, and K.H.J. Buschow, New class of materials: half-metallic ferrowmagnets, Phys. Rev. Lett. 50, 2024-2027 (1983), https://doi.org/10.1103/PhysRevLett.50.2024.

[11] J. Kübler, A.R. William, C.B. Sommers, Phys. Rev. B, 28, 1745-1755 (1983), https://doi.org/10.1103/PhysRevB.28.1745.

[12] M.I. Katsnelson, V.Yu. Irkhin, L. Chioncel, A.I. Lichtenstein, and R.A. de Groot, Rev. Mod. Phys. 80, 315-378 (2008), https://doi.org/10.1103/RevModPhys.80.315.

[13] Igor Žutić, J. Fabian, and S. Das Sarma, Rev. Mod. Phys. 76, 323-410 (2004), https://doi.org/10.1103/RevModPhys.76.323.

[14] H. Ohno, Science, 281, 951-956 (1998), https://doi.org/10.1126/science.281.5379.951.

[15] J.D. Boeck, W.V. Roy, J. Das, V. Motsnyi, Z. Liu, L. Lagae, H. Boeve, K. Dessein, and G. Borghs, Semicond. Sci. Technol. 17, 342 (2002), https://doi.org/10.1088/0268-1242/17/4/307.

[16] S. Ishida, S. Akazawa, Y. Kubo, and J. Ishida, J. Phys. F: Met. Phys. 12, 1111 (1982), https://doi.org/10.1088/0305-4608/12/6/012.

[17] I. Galanakis, K. Özdoğan, E. Şaşığlu, and B. Aktaş, Phys. Rev. B, 75, 092407 (2007), https://doi.org/10.1103/PhysRevB.75.092407.

[18] R.Y. Umetsu, K. Kobayashi, R. Kainuma, A. Fujita, K. Fukamichi, K. Ishida, and A. Sakuma, Appl. Phys. Lett. 85, 2011-2013 (2004), https://doi.org/10.1063/1.1790029.

[19] Y. Miura, K. Nagao, and M. Shirai, Phys. Rev. B, 69, 144413 (2004), https://doi.org/10.1103/PhysRevB.69.144413.

[20] K. Seema, N.M. Umran, and R. Kumar, J. Supercond. Nov. Magn. 29, 401-408 (2016), https://doi.org/10.1007/s10948-015-3271-7.

[21] E. Wimmer, H. Krakauer, M. Weinert, and A.J. Freeman, Phys. Rev. B, 24, 864-875 (1981), https://doi.org/10.1103/PhysRevB.24.864.

[22] P. Blaha, K. Schwarz, G.K.H. Madsen, D. Kvasnicka, and J. Luitz in: WIEN2k: An Augmented Plane Wave + Local Orbitals Program for Calculating Crystal Properties, edited by K Schwarz (Technical Universitatwien, Austria, 2001), pp. 287.

[23] E. Sjöstedt, L. Nordström, and D.J. Singh, Solid State Commun. 114, 15-20 (2000), https://doi.org/10.1016/S0038-1098(99)00577-3.

[24] J.P. Perdew, K. Burke, and M. Ernzerhof, Phys. Rev. Lett. 77, 3865-3868 (1996), https://doi.org/10.1103/PhysRevLett.77.3865.

[25] Atomistix ToolKit-Virtual Nanolab (ATK-VNL), QuantumWise Simulator, Version. 2014.3. Available: http://quantumwise.com/

[26] Y.J. Lee, M. Brandbyge, J. Puska, J. Taylor, K. Stokbro, and M. Nieminen, Phys. Rev. B, 69, 125409 (2004), https://doi.org/10.1103/PhysRevB.69.125409.

[27] K. Schwarz, J. Solid State Chem. 176, 319-328 (2003), https://doi.org/10.1016/S0022-4596(03)00213-5.

[28] P. Pulay, J. Comput. Chem. 3, 556-560 (1982), https://doi.org/10.1002/jcc.540030413.

[29] H.J. Monkhorst, and J.D. Pack, Phys. Rev. B, 13, 5188-5192 (1976), https://doi.org/10.1103/PhysRevB.13.5188. 
[30] T. Hahn, A. Looijenga-Vos, M.I. Aroyo, H.D. Flack, K. Momma, and P. Konstantinov, edited by M. Aroyo, in: International Tables for Crystal-lography Volume A: Space-group Symmetry, (Springer Netherlands, Dordrecht, 2016), pp. 193-687, http://dx.doi.org/10.1107/97809553602060000114.

[31] M.J. Mehl, D. Hicks, C. Toher, O. Levy, R.M. Hanson, G.L.W. Hart, and S. Curtarolo, Comput. Mater. Sci. 136, S1-S828 (2017), https://doi.org/10.1016/j.commatsci.2017.01.017.

[32] F.D. Murnaghan, Proc. Natl. Acad. Sci. U.S.A, 30, 244-247 (1944), https://dx.doi.org/10.1073\%2Fpnas.30.9.244.

[33] I. Galanakis, P.H. Dederichs, and N. Papanikolaou, Phys. Rev. B, 66, 134428 (2002), https://doi.org/10.1103/PhysRevB.66.134428.

[34] C.M. Fang, G.A. de Wijs, and R.A. de Groot, J. Appl. Phys. 91, 8340 (2002), https://doi.org/10.1063/1.1452238.

[35] R. Jain, N. lakshmi, V. K. Jain, V. Jain, A.R. Chandra, and K. Venugopalan, J. Magn. Magn. Mater. 448, 278-286 (2018), https://doi.org/10.1016/j.jmmm.2017.06.074.

[36] S. Sharma, A.S. Verma, and V.K. Jindal, Mat. Res. Bull. 53, 218-233 (2014), https://doi.org/10.1016/j.materresbull.2014.02.021.

\section{ПЕРШООСНОВИ РОЗРАХУНКУ ЕЛЕКТРОННИХ, ОПТИЧНИХ І МАГНІТНИХ ВЛАСТИВОСТЕЙ ПОВНИХ СПОЛУК ХЕЙСЛЕРА \\ Сукхендер ${ }^{a}$, Правеш ${ }^{b}$, Лаліт Мохан ${ }^{a}$, Аджай Сінгх Верма ${ }^{a}$ \\ ${ }^{a}$ Факультет фізики, Банастхалі Відьяпітх, Банастхалі 304022, Індія \\ ${ }^{b}$ Факультет електроніки і техніки звязку, група установ КIЕT} Газіабад, Уттар-Прадеш, Індія, 201206

Для дослідження структурних, електронних, оптичних і магнітних властивостей сполук $\mathrm{Co}_{2} \mathrm{CrZ}(\mathrm{Z}=\mathrm{In}, \mathrm{Sb}, \mathrm{Sn})$ ми використовували два різних методи. Один з них базується на методі повної потенційної лінеарізованої розширеної плоскої хвилі (FP-LAPW), який є реалізованим у коді WIEN2k, а другий - на псевдопотенційному методі, реалізованому в Аtomistic Tool Kit-Virtual NanoLab (ATK-VNL). Для цих сполук $є$ характерною нульова ширина енергетичної щілини як для основної

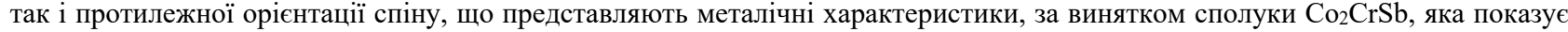
ширину енергетичної щілини $0,54 \mathrm{eB}$ для протилежної орієнтації спіну поблизу рівня Фермі, і спостерігається $100 \%$-на спінова поляризація; всі ці дані отримані з використанням коду WIEN2k. Крім того, було виявлено, що сполука $\mathrm{Co}_{2} \mathrm{CrSb} \epsilon$ ідеальним напівметалевим феромагнетиком (HMF). У той же час, при використанні коду ATK-VNL для вищезазначених сполук має місце нульова енергетична щілина. Розрахунки, що були виконані з використанням коду WIEN2k, показують

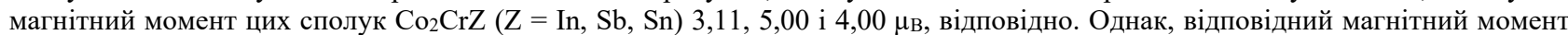
цих сполук у коді ATK-VNL становить $3,14,5,05$ i 4,12 $\mu$ в. Розраховані магнітні моменти добре узгоджуються з властивостями по Слейтер-Полінгу. Оптичні властивості відіграють важливу роль у розумінні природи матеріалу, що використовується для вивчення оптичних явищ, а також використовуються в пристроях оптоелектроніки. Значення коефіцієнта поглинання та оптичної провідності для $\mathrm{Co}_{2} \mathrm{CrSb} \epsilon$ більшим, ніж для двох інших сполук. Зі співвідношення спектрів поглинання і відбиття видно, що поглинання і відбивна здатність $є$ обернено пропорційними один одному.

КЛЮЧОВІ СЛОВА: напівметалевий феромагнетик, ширина енергетичної щілини, щільність стану, спінова електроніка

\section{ПЕРВООСНОВЫ РАСЧЕТА ЭЛЕКТРОННЫХ, ОПТИЧЕСКИХ И МАГНИТНЫХ СВОЙСТВ ПОЛНЫХ СОЕДИНЕНИЙ ХЕЙСЛЕРА \\ Сукхендер $^{a}$, Правеш ${ }^{\mathrm{b}}$, Лалит Мохан ${ }^{\mathrm{a}}$, Аджай Сингх Верма ${ }^{\mathrm{a}}$ \\ а Факультет физики, Банастхали Видьяпитх, Банастхали 304022, Индия \\ ${ }^{b}$ Факультет электроники и техники связи, Группа учреждений КIЕT \\ Газиабад, Уттар-Прадеш (Индия) 201206}

Для исследования структурных, электронных, оптических и магнитных свойств соединений $\mathrm{Co}_{2} \mathrm{CrZ}(\mathrm{Z}=\mathrm{In}, \mathrm{Sb}, \mathrm{Sn})$ мы использовали два разных метода. Один из них основан на методе полной потенциальной линеаризованной расширенной плоской волны (FP-LAPW), реализованном в коде WIEN2k, а второй - на псевдопотенциальном методе, реализованном в Atomistic Tool Kit-Virtual NanoLab (ATK-VNL). Для этих соединений характерна нулевая ширина энергетической щели как для основной так и противоположной ориентации спина, представляющих металлические характеристики, за исключением соединения $\mathrm{Co}_{2} \mathrm{CrSb}$, которое показывает ширину энергетической щели 0,54 эВ с противоположной ориентации спина вблизи уровня Ферми, и наблюдается 100\%-ная спиновая поляризация; все эти данные получены с использованием кода WIEN2k. Кроме того, было обнаружено, что соединение $\mathrm{Co}_{2} \mathrm{CrSb}$ является идеальным полуметаллическим ферромагнетиком (HMF). B то же время, при использовании кода ATK-VNL для вышеупомянутых соединений имеет место нулевая энергетическая щель. Расчеты, выполненные с использованием кода WIEN2k, показывают магнитный момент этих соединений Со2 $\mathrm{CrZ}$ ( $\mathrm{Z}=\mathrm{In}, \mathrm{Sb}, \mathrm{Sn}) 3,11,5,00$ и 4,00 $\mu$ в, соответственно. Однако соответствующий магнитный момент этих соединений в коде ATK-VNL составляет 3,14, 5,05 и 4,12 $\mu$ в. Рассчитанные магнитные моменты хорошо согласуются со свойствами по СлейтерПолингу. Оптические свойства играют важную роль в понимании природы материала, используемого для изучения оптических явлений, а также используемых в устройствах оптоэлектроники. Значение коэффициента поглощения и оптической проводимости для $\mathrm{Co}_{2} \mathrm{CrSb}$ больше, чем для двух других соединений. Из соотношения спектров поглощения и отражения видно, что поглощение и отражательная способность обратно пропорциональны друг другу.

КЛЮЧЕВЫЕ СЛОВА: полуметаллический ферромагнетик, ширина энергетической щели, плотность состояния, спиновая электроника 